\title{
Imperial expansion and its critics
}

In May 1910 Edward VII, king of Great Britain and Ireland and emperor of India, who had assumed the throne on the death of his mother Queen Victoria in 1901, died at the age of 68. He had worn the Crown which held together an Empire of formidable extent that ranged across a quarter of the globe and included over 300 million people. ${ }^{1}$ Of these, nearly 19 million were settlers, most of British origin, in the White Dominions of Canada, Australia, New Zealand and the newly united South Africa, the economic transactions of which constituted 16.5 per cent of Britain's overseas trade. ${ }^{2}$ Edward's son and successor George V had visited all of these Dominions, a feat not matched by his father and grandmother. King George's coronation, scheduled for 22 June the following year, provided a suitable occasion for the prime minister of Britain, H. H. Asquith, to call together Dominion representatives for an Imperial Conference. The first Imperial Conference had coincided with Queen Victoria's Golden Jubilee, in 1887, and several mutually advantageous meetings had occurred subsequently, the most recent having been in $1907 . .^{3}$ At this juncture, with international tensions brewing, the most urgent business for the British Liberal Government was to unite the Dominions around issues of defence.

And so in May 1911 the prime ministers of the Dominions, flanked by their appropriate ministers, set foot in the British capital, all apparently pleased, if not flattered, to be there to receive the applause of the press and the assiduous attentions of the senior ministry and royal family. From the newly united South Africa came its first prime minister, General Louis Botha, recently commandant-general of the defeated Boer army. The long-serving French-Canadian Liberal Prime Minister Sir Wilfred Laurier represented Canada. Also from Laurier's sphere, but separate from Canada, was Sir Edward Morris of Newfoundland, which had stayed outside the Confederation. From the Commonwealth of Australia came Mr Andrew Fisher, the first Australian Labor Party man 
to reach the highest office since the colonies had federated, in 1901. Sir Joseph Ward arrived from the most ostentatiously loyal Dominion, New Zealand, the island group east of Australia that, like Newfoundland, had decided to go it alone. On arrival in London Ward spoke probably for them all when he declared that New Zealand stood for 'the old flag, a White country, an invincible Imperial Navy, with an adequate share of responsibility, extension of trade within the Empire, and representation on an Imperial Council' ${ }^{4}{ }^{4}$

Whatever the ostensible business of the sessions, the Imperial Conference of 1911 was an unashamed celebration of White supremacy in these sites of settler colonisation. Asquith opened the Imperial Conference on the morning of 23 May, Empire Day, in an atmosphere, according to The Times, that was without pomp though not without dignity. Matters affecting 'the whole future of our race' depended on the wisdom and statesmanship of the six prime ministers, Asquith declared. Two features that were unique to this Empire were the rule of law and the combination of local autonomy with loyalty to a common head. He observed also with particular satisfaction 'our common trusteeship for the interests and fortunes of those of our fellow-subjects who have not yet attained, and some of whom may never attain, to the full estate of self-government $t^{\prime}{ }^{5}$ Fisher congratulated the mother country on the first of these points when he said: 'The British Empire alone had been able to develop self-governing institutions which were associated by almost unseen, but none the less real, ties of loyalty with the British people. ${ }^{16}$ But Fisher did not engage with the morality of 'common trusteeship': Australia's interests lay in gaining delegates' backing on exclusionary policies grounded in race. He wanted no direct allusions to the civil rights of Aborigines, and sought overt imperial sympathy for keeping borders closed to non-European migrants, whether from countries of the Empire or not. Ward agreed. From New Zealand's point of view, he said, 'the matter of racial purity' ranked in importance with defence. ${ }^{7}$ Lord Crewe, the British colonial secretary, was hesitant. He advised that the administration of such laws ought to be mild in case Australia's ability to enforce them should diminish: 'to make them needlessly irritating in the meantime would be a blunder worse than a crime' ${ }^{8}$

Outside this gathering, but closely monitoring its proceedings, was a group of men from an organisation that had long-standing concerns (dating back to the 1830s) for Indigenous peoples across the Empire. The men from the humanitarian Anti-Slavery and Aborigines' Protection Society (ASAPS) grasped the opportunity to make personal contact with General Botha in order to object to the franchise provisions in the new Union of South Africa. Almost all Indigenous Africans were explicitly 


\section{IMPERIAL EXPANSION AND ITS CRITICS}

excluded from the franchise - and all from representation in the Union's Legislature. The men from ASAPS reminded Botha that every member of the imperial Parliament who had spoken in the House of Commons' debate on the Act of Union of 1910 had protested about 'the provisions known as "the colour bar"'. The Society earnestly hoped that the electorate and the government of the South African Dominion 'may soon see their way to such amendments ... as will remove this grievous blot on a great instrument of justice and conciliation', thus opening the way for 'the enfranchisement of all classes of His Majesty's subjects in South Africa, subject only to such conditions of capacity as may properly be applied to all alike, without distinction of colour or descent'. ${ }^{\prime}$ The ASAPS men sought to make personal contact with General Botha, but he left town abruptly. ${ }^{10}$ The Society's members contented themselves with some discussion of the South African 'Native Question' with W. P. Schreiner, KC, a senator in the South African parliament and a former prime minister of the Cape who was coincidentally in London for the Universal Races Congress. Schreiner was notable in humanitarian circles as one politician who had resisted the colour bar in the Union Constitution, albeit unsuccessfully.

None of the prime ministers would have welcomed reminders of social justice and equity issues relating to their Indigenous peoples in countries the whiteness of which they asserted at every turn. The leaders of Australia, Canada and New Zealand all presided over political arrangements that, as in South Africa, indicated unfavourable political status for Indigenous peoples, however cleverly the situation was rationalised. This might seem scarcely unexpected, given the ruthlessness of British and other European settlers' appropriation of Indigenous peoples' land, labour and livelihoods throughout the nineteenth century. But it is important to note that the settlements over political rights in place by the early twentieth century were the outcome of considerable negotiations between competing groups, each with a vital stake in the nature of the so-called democratic governments that these Dominions supported. Close attention to the critical moments in imperial history in the 1830s will clarify our understanding of the new directions of the Victorian age. To the fore were twin tensions between those players with humanitarian and liberal ideals, on the one hand, and those whose job it was to pursue pragmatically the smooth implementation of British governmental policies, on the other.

First, however, we trace the story of the expansion of the British Empire up to the mid-1830s and, in particular, Britain's gradual acquisition of settler colonies as men and women of European origin appropriated Indigenous peoples' lands in North America, southern Africa and Australasia. 


\section{Imperial expansion to the 1830s}

The loss of the eastern Atlantic seaboard colonies that constituted the United States of America following the War of Independence posed merely a temporary setback to British imperial expansion. It did, however, mark a shift in the response of British governments to settler demands for local control of areas in those colonies where considerable numbers of British settlers congregated. Undoubtedly India with its riches constituted by far the most important of Britain's possessions, with the Caribbean Islands perhaps second. Yet by the mid-1830s the sites of White occupation, where the British sought to form permanent settlements, were already assuming significance as they grew in prosperity and confidence, whatever the divisions among settlers themselves. The different colonies had by that date already widely varying background histories of their foundations and experiences of settler relationships with Indigenous peoples. ${ }^{11}$

The Indigenous people of the area that would become Canada had a substantial history of trading relationships with Europeans before they faced any threat to their lands. ${ }^{12}$ Although contact brought some diminution in Indigenous populations through the impact of displacement and disease, conflict was muted as both fur-traders and fishermen needed to seek the co-operation of local residents in order to survive and profit in the harsh climatic conditions. This dependence lessened with the establishing of permanent settlements by the French, beginning with Port-Royal, Nova Scotia, in 1605 . While the informal colonisation of Newfoundland, which commenced in 1610, was to take a heavy toll of the local Beothuk people, on the mainland Indigenous people found a place in the new order by forming military alliances with competing French and British forces. Britain gained its first colony in what would become Canada in 1713, when the French ceded Nova Scotia under the Treaty of Utrecht, although few immigrants arrived in the new colony until Halifax had been established by Colonel Edward Cornwallis and 2,600 European Protestants in 1749.

It was only with the deportation of the original French settlers, the Acadians, following the resumption of war in 1754, that substantial immigration of English speaking colonists, both from Britain and New England, began. In 1758 the British took possession of Île St John which in 1769 was separated from Nova Scotia to become the Prince Edward Island Colony, with land distributed among individuals who had earned merit during the Seven Years' War, on the condition that it be leased to Protestant settlers. With the signing of the Treaty of Paris in 1763 the remaining French territory came under British control. New France became the British colony of Quebec (known after 1791 as Lower 


\section{IMPERIAL EXPANSION AND ITS CRITICS}

Canada), its population predominantly of French descent but with a small settlement of English merchants and traders at Montreal. By the time Newfoundland formally became a British colony in 1824 the Beothuk had been subjected to what amounted to genocide. ${ }^{13}$ As settlement advanced in other areas a similar fate seemed likely for the Indigenous peoples who were being progressively displaced. Between the 1790s and the 1820s smallpox, tuberculosis and measles took a heavy toll among the bands resettled around the Great Lakes, a pattern that would be repeated as settlement spread across the country.

With the cessation of conflict the British need for continuing military alliances with Indigenous peoples declined. The basis on which the country was to be shared was set out in the Royal Proclamation of 1763 that defined the boundaries of the new colonies, closing all other lands to settlement except through treaties negotiated between 'Indian' or First Nations' peoples and the Crown. Under this agreement the Indigenous people located outside the new colonies were subject to intrusions from both traders and missionaries but they ruled themselves and remained in possession of their lands. This position began to change dramatically with Britain's loss of its American colonies. In the 1783 Treaty of Versailles, the British surrendered all claims to lands south of the new border, whether held by their Indigenous allies or the American rebels. Needing to provide land for dispossessed Loyalists, and anxious to increase the population in their remaining territories in order to resist further American intrusion, they began to exercise the land transfer provisions implicit in the Royal Proclamation, negotiating with Indigenous peoples adjacent to the existing settlements to exchange their large tracts of land for secure reserves.

Even before such transfers could be arranged, incoming colonists 'squatted' on lands not yet ceded at the limits of settlement, establishing a claim that later governments would prove unwilling to contest. New settlements in New Brunswick, separated from Nova Scotia in 1784, Upper Canada (Ontario) in 1791, and Red River (subsequently Manitoba) in 1811 provided further centres from which European influence could expand, increasing the pressure on Indigenous lands and sovereignty. The rest of the vast territory remained under the control of the Hudson's Bay Company, which, while trading with Indigenous peoples, left them otherwise little disturbed. Missionaries, however, were increasingly active in the territory, Catholics expanding from their original base in New France and Protestants, particularly American Wesleyans, moving in advance of Loyalists into the new territories. Indigenous leaders were active in negotiating with such missionaries, seldom completely rejecting the 'civilising mission' but 
anxious to keep control of the changes that were being wrought in their communities.

European colonisation in Southern Africa was almost as long established as in British North America. It had begun in 1652, when the Dutch East India Company (VOC) established a small settlement with a fort at Table Bay on the Cape peninsula in the extreme south-west of the country to serve as a 'refreshment station' for its ships rounding the Cape on their way to and from the Dutch East Indies. Here they came into contact with the Indigenous Khoisan peoples, comprising the Khoikhoi (nomadic pastoralists whom the Dutch called Hottentots) and the San (hunter-gatherers, whom the Dutch stigmatised as 'bushmen'). Over the next century-and-a-half, the settlement gradually expanded northwards and eastwards out of the peninsula. The VOC was concerned only to maintain Cape Town and the harbour on Table Bay for their ships, and had no interest in moving into the interior; but the free settlers who arrived from the Netherlands (with some Germans and Huguenots from France) craved land for themselves and their cattle, and kept moving away from VOC control in Cape Town into the interior. Arid climatic conditions along the west coast and the semi-desert of the Great Karoo limited the extent of their northward penetration; the main movement of small groups of Trekboers (travelling farmers) during the eighteenth century was eastwards, along the coastline and parts of the inland plateau not too far from the coast. As they moved away from VOC control, these Dutch settlers began to refer to themselves as Afrikaners (Africans) and the dialect of Dutch which they spoke as Afrikaans.

The initial effects on the Indigenous peoples were disastrous. When the Khoi realised that the Dutch intended to stay permanently, they resisted militarily, but - with the Dutch having the use of firearms and the Khoi able to muster only relatively small and poorly armed bands for fighting - they were fairly easily defeated in two wars in 1659 and 1673-76. The devastating effect of these defeats, and of the land dispossession which accompanied them, were compounded by another weapon which the Dutch, as also the French and British in North America, had brought with them - disease: the Khoi were decimated by a smallpox epidemic in 1713, against which they had little resistance. And the damage was completed by the devastating effect of Dutch gin and brandy on people unused to distilled liquors. By the end of the eighteenth century, the Khoi had lost most of their independent communal structure. They were now found working mainly for the Dutch - as servants on farms or colonial soldiers in a 'Hottentot' regiment under White officers - eking out a living on the fringes of Cape Town, or living and working on one of the few mission stations which had 


\section{IMPERIAL EXPANSION AND ITS CRITICS}

been set up in the interior. Use of their language declined as well, being replaced largely by Afrikaans. The fate of the San was even worse. They resisted the invading farmers by guerrilla warfare, with small-scale attacks on farmers and their cattle; in return, they were hunted down like vermin and killed when the farmers' commandos could find them. They were gradually driven north, into the Namib and Kalahari Deserts.

The VOC further complicated the ethnic mix of the colony by transporting slaves - about 60,000 of them brought, between 1652 and 1807, by the VOC from the Dutch East Indies, the Indian Ocean and parts of the east coast of Africa - to do most of the work in Cape Town and the farms of the Cape peninsula. Masters sometimes freed individual slaves, but the system of slavery remained intact at the Cape until 1834. Out of this complex ethnic mix - Khoisan, slaves and ex-slaves, and the children of sexual union between Dutch men and Indigenous or slave women - came the distinctive group who came to be known, by the 1830s, as the 'Cape Coloured people'. These men and women lived mainly in the western Cape, in and around Cape Town, speaking their own distinctive brand of what became the Afrikaans language.

The late eighteenth century brought two crucial changes to the course of developments in the VOC colony. First, in the 1770s, the eastward movement of the Trekboers was brought to a sudden halt around a number of rivers in the eastern Cape, when they ran into the forward groups of a large people, the Bantu-speaking Xhosa. ${ }^{14}$ Like all the Bantuspeaking peoples, and unlike the Khoisan, the Xhosa were agro-pastoralists, keeping cattle on a large scale and also growing crops. Though politically divided into a number of major groups - the Gqunukhwebe, Ndlambe, Ngqika and Gcaleka Xhosa, the Thembu and Mpondo - their overall number was large, and they were in dense occupation of their territory, competing with the White farmers for access to the same pasture and water resources. They also presented a far more formidable military opposition than the Khoisan had done; in the event of war, they could mobilise large numbers of relatively well-disciplined men, armed with iron spears. As an opposing force they could not be easily brushed aside by the farmers, greedy to take their land. The result was the development of what became known as the 'Eastern Frontier' of the Cape, as a series of wars broke out, the first in the years 1779-81 (the area would see no fewer than nine such frontier wars). ${ }^{15}$ The various Xhosa-speaking groups put up a formidable resistance: the nineteenth century wars lasted for a number of years and required the use of large numbers of regular British troops to defeat them - but the superior technological and logistical basis of the colonial forces ultimately ensured their victory in each war (see chapter 4). 


\section{CLAIMING A SECOND EMPIRE}

The second significant change was in the European control of the colony, which passed from the Dutch to the British. During the French Revolutionary and the Napoleonic Wars, the British took the Cape from the Dutch - in 1795 (but handed it back, as part of the Truce of Amiens, in 1803) and again in 1806. The second time, British rule was there to stay: at the end of the wars, in 1815, Britain was granted permanent rule over the colony. By the time at which we begin our examination of the colonies of settlement - the mid-1830s - Britain had been governing the Cape Colony for two decades. British missionaries from the London Missionary Society (LMS) had established themselves in Southern Africa, as had Methodists, all of whom joined German Moravians to convert and offer Western education to Indigenous peoples.

British settlement in the southern Pacific occurred subsequent to Britain's loss of its North American colonies and directly as a result of that loss. The colonies of Virginia and Maryland had been the repository for convicted offenders in an attempt to relieve overcrowded British jails. Following the loss of the war with the American colonists, the British needed to look elsewhere, and for their alternative penal colony chose a site on the eastern coast of the island continent of Australia. It had been the English explorer Captain James Cook whose voyages in the late eighteenth century brought the continent of Australia to British attention, along with neighbouring islands including those of New Zealand. In January 1788 the first British officers and convicts reached the east-coast harbour they named Sydney, just one year after the drafting of the American Constitution. The first British settlement was thus backed by a contingent of marines (none of the early governors had many troops in Australia, especially as compared to the larger number used in South Africa and New Zealand). The officers carried British Government orders to deal peaceably with any Aborigines they encountered, though they expected few. Reports from Cook's officers, especially Sir Joseph Banks, suggested few Indigenous inhabitants, and these few as 'wanderers', hunter-gatherers with no established attachment to the land. ${ }^{16}$ Friendly gestures ceased at the initial sign that Aborigines might repel the British as intruders and enemies, and the first killing of an Aborigine took place. Over the next few decades more convicts arrived, as did more soldiers, and some free settlers. The cautious but persistent spread of settlement up rivers into the hinterland and across the Bass Strait into Van Diemen's Land (proclaimed a separate colony in 1826 and subsequently called Tasmania) was accompanied by armed reprisals against Aboriginal resisters; as in Newfoundland, the result was near-genocide. Settlement proceeded in which the colonial authorities tolerated the appropriation of land with 
no thought of negotiations, treaties or compensation. Aboriginal bands were small and isolated, comprised of men and women, young and old - not a match for settlers' firepower. The warfare resulted in the death of some settlers and of hundreds of Aborigines; European diseases again wreaked havoc. The pattern was repeated throughout the 1820 s as pastoralist entrepreneurs, or 'squatters', and their convict workers, with herds of sheep and cattle, broke through the official bounds of settlement to pour across the plains beyond the Blue Mountains, killing some Aborigines, terrorising others. Aborigines were rapidly turned into unwelcome impediments to the progress of British settlement, enemies of the British Crown that now claimed ownership of all their country. The missionary societies that had operated in the Pacific Islands from 1797 - the London Missionary Society, the Church Missionary Society (CMS), the Wesleyan Methodist Missionary Society (WMMS) - could scarcely sustain a foothold on the continent of Australia to provide protection or advocacy for the Indigenous groups which had become their protégés. The missions were swamped by the fast moving frontier of settler occupation, as missionaries saw their protégés decimated before their eyes. ${ }^{17}$ By the mid-1830s similar tragedies were in train as voracious settlers set foot in new areas, including the Port Phillip District (later Victoria) to the south and the new colony of South Australia. ${ }^{18}$

As early as the end of the 1780s convicts had left New South Wales to try their luck beyond the reaches of the British law in the islands of New Zealand across the Tasman Sea. Other adventurers arrived to stay, and also missionaries, following the visit of the New South Wales chaplain the Reverend Samuel Marsden to the northern Bay of Islands in 1814. White settlement was slow. Maori, horticulturalists, were not only numerous, but firmly in control of fertile ground and organised into hostile clans. They turned on Europeans with ferocity if conventions were breached. Maori acquired guns through trade with ships' crews, faced no military force, and remained in control. Some responded to missionary teaching, became Christians and learned to read and write in their own tongue. A number of adventurers lived with Maori, found sexual partners in young Maori women, and wrote for a British audience with a degree of sympathy towards Maori culture. Reports of Maori problems with unruly visitors led the British Government to consider placing New Zealand under the distant oversight of the governor of New South Wales, but Maori chiefs remained in control of their separate tribal areas. In 1832 the Colonial Office appointed James Busby as British resident at the Bay of Islands, and in 1835 with his assistance thirty-five northern chiefs signed a declaration of independence to prevent yet other nations from intruding. But they 
could not remain isolated from the colonising project that had gripped the coast of Australia. Back in England the New Zealand Company, urged on by Edward Gibbon Wakefield, began preparations to launch a 'planned' colony in the southern portion of the North Island. ${ }^{19}$ The Maori had thus far been spared the atrocities that had marked the settlement of New South Wales; but that reprieve would be only temporary were the rapid unregulated colonisation to continue.

How was the burgeoning population of British abroad - and other Europeans now occupying lands claimed as part of the British Empireto be governed? Having learnt from its American experience, the British government was sensitive to a model of colonisation that recognised the right of incoming compatriots to have a substantial voice in decision-making and administration at the local level within settler colonies. The colonies in Canada had received representative government in the late eighteenth century. From 1758, Novia Scotians had the right to vote for a council to assist the governors, based on a substantial property franchise. That arrangement was extended to Prince Edward Island in 1773, New Brunswick in 1785, and Lower and Upper Canada in 1792. While the chiefs of the various First Nations could still represent their claims to the governor in his guise as protector and military commander, the elite among the colonists now had more immediate access through their role in the newly established legislatures.

Throughout the early decades of the nineteenth centuries, it was the Colonial Office in London that conducted the day-to-day administration of the Empire. The British Government established the Colonial Office in 1801 as the administrative department that would deal with the Empire's affairs. ${ }^{20}$ The secretary of state for the colonies (initially for war and the colonies), from this time a senior minister in the Cabinet, served at the head of this department, assisted by a junior minister or parliamentary under-secretary. From 1825 onwards a civil servant served as a permanent under-secretary. Gradually, as their business expanded, to the extent that their workload became a burden, the officers were likely to tend towards support for the colonies' selfgovernment in local affairs rather than engage in a struggle for control, and usually accepted the advice of the governors in place.

Very near the start of our period, in the later 1830s, British imperial policies towards the rights of the Indigenous peoples of the Empire, and towards the political rights of settlers, made as they were from the Empire's centre in London, showed a degree of uniformity, from which the settler colonies would later diverge. We can illustrate the key tensions from which these differing paths emerged by examining the content, recommendations and subsequent implementation of two influential reports, both emanating from the British Parliament of the 1830s. Both 


\section{IMPERIAL EXPANSION AND ITS CRITICS}

reports offered useful information on the state of British colonies at the time, and set much of the pattern for tensions in the government of the settler colonies' development over the next decades. These are the Report of the Select Committee on Aborigines, of 1837, ${ }^{21}$ and the Report on the Affairs of British North America, or the Durham Report, of 1839. ${ }^{22}$

\section{British humanitarians and imperial injustices}

The British may have had concerns about their fellow-subjects abroad in the 1830s, but first they had major antagonists who confronted them close to home. These were groups of evangelicals who, during the 1830s, organised around imperial and international concerns, and who had strong allies in the missionaries who had left England to carry a Christian message abroad. The humanitarians gathered in two lobby groups with overlapping memberships and concerns: the Anti-Slavery Society, founded in 1823, and particularly the Aborigines' Protection Society, founded in 1837 . The enormous energy generated by the evangelical revival of the late eighteenth century which had led to the formation of the missionary societies had great impact also within Britain. Above all, William Wilberforce inspired the anti-slavery campaign taken up by a number of leading evangelicals who had similarly worked towards the ending of slavery in the British Empire. After the 1833 Act that provided for the phasing out of slavery - influential above all for the Caribbean, but also for Africa, including the Cape - evangelicals, led now by Sir Thomas Fowell Buxton, began to turn their attention to another pressing scandal: the position of Indigenous peoples, or 'Aborigines', across the British Empire.

The Report of the Select Committee on Aborigines was largely the work of evangelical MPs. ${ }^{23}$ The Select Committee's chairman was the prominent evangelical Sir Thomas Fowell Buxton, ${ }^{24}$ who had taken over the leadership of the anti-slavery movement when William Wilberforce retired, and had succeeded in 1833 in getting through Parliament an Act to abolish slavery throughout the British Empire. Buxton moved smoothly, in a logical progression from anti-slavery to the cause of the protection of Indigenous peoples within the British Empire. He induced the House of Commons to set up the Select Committee in 1835; and in 1837, the year in which the Committee handed down its Report, he founded the Aborigines' Protection Society (APS), with its London base in Exeter Hall and branches established in the colonies. Buxton filled the Committee with like-minded evangelical MPs, who could be counted on to advocate policies to deal with the adverse impact of British colonisation on the Indigenous peoples of the British colonies. 


\section{CLAIMING A SECOND EMPIRE}

The late 1830s was an auspicious time for Buxton and his Committee to be advocating such policies, since, for a short time, the formation and implementation of British colonial policy was under considerable evangelical influence. Charles Grant, the son of Charles Grant of Wilberforce's original 'Clapham Sect', was created Lord Glenelg and appointed colonial secretary in April 1835; his parliamentary under-secretary was Sir George Grey, an active evangelical and member of the Select Committee. James (subsequently Sir James) Stephen, son of James Stephen of the 'Clapham Sect', became permanent under-secretary at the Colonial Office in 1836; during what would be eleven years in that post, he became known as 'Mr Mother Country', and he exerted a very strong influence over all aspects of British colonial policy.

The Select Committee took a great deal of evidence, from witnesses and from correspondents; and it produced a large report, in which its members evinced considerable concern at the adverse impact of White settlers on the Indigenous peoples of the British colonies of settlement. ${ }^{25}$ The bulk of the witnesses - missionaries, military men and administrators - gave detailed evidence about the Cape Colony in South Africa. The evidence about the Cape focused on two issues in particular: the decline in the state of the Khoikhoi people (to whom the Committee referred as 'Hottentots') under White colonisation; and the violent 'Eastern Frontier', where the colonists and the Xhosa people (whom the Committee called Caffres) had fought no fewer than six bloody frontier wars since 1779, the most recent being in 1834. The Committee also showed concern about the Australian colonies, and the near-genocide of the Aborigines of Van Diemen's Land in just three decades of British settlement of that island. Witnesses and the Committee's Report highlighted the fate of the original Tasmanians as horrific, both in itself and in its implications for the impact on the Indigenous peoples of further settlement in the Port Phillip district of New South Wales from 1835; the foundation of the new colony of South Australia in 1836; and the likelihood of imminent British colonisation of New Zealand and possibly of other islands in the south Pacific. And they made some mention - more briefly, but still with some substantial evidence - of developments in 'British North America' (Canada) and in the south Pacific, including New Zealand.

The Report betrays an uneasy awareness that, thus far, the effect of British colonisation on Indigenous peoples, in widely separated parts of the world, had been disastrous:

It is not too much to say, that the intercourse of Europeans in general, without any exception in favour of the subjects of Great Britain, has been, unless when attended by missionary exertions, a source of many calamities to uncivilized nations. 


\section{IMPERIAL EXPANSION AND ITS CRITICS}

Too often their territory has been usurped; their property seized; their numbers diminished; their character debased; the spread of civilization impeded. European vices and diseases have been introduced amongst them, and they have been familiarized with the use of our most potent instruments for the subtle or violent destruction of human life, viz. brandy and gunpowder. ${ }^{26}$

The evangelicals were strong believers in Providence - the conviction that God actively intervened in human affairs for His own purpose. Surely He could not have intended these evil consequences to follow from colonisation?

The British Empire had been signally blessed by Providence, the Report continued, and 'her eminence, strength, wealth and prosperity, her intellectual, her moral and her religious advantages, are so many reasons for peculiar obedience to the laws of Him who guides the destinies of nations':

They were given for some higher purpose than commercial prosperity and military renown . . 'Can we suppose otherwise than that it is our office to carry civilization and humanity, peace and government, and, above all, the knowledge of the true God, to the uttermost ends of the earth?' He who has made Great Britain what she is, will inquire at our hands how we have employed the influence He has lent us in our dealings with the untutored and defenceless savage, whether it has been engaged in seizing their land, warring upon their people, and transplanting unknown disease, and deeper degradation, through the remote regions of the earth; or whether we have, as far as we have been able, informed their ignorance, and invited and afforded them the opportunity of becoming partakers of that civilization, that innocent commerce, that knowledge and faith with which it has pleased a gracious Providence to bless our own country. ${ }^{27}$

It was through this argument that the evangelicals of the Committee reconciled themselves to, and justified, the continued existence and progress of the British Empire. Its purpose was to bring to the Indigenous peoples the blessings of true 'civilisation', and in that way do God's work. With this in mind, the Select Committee framed a series of recommendations to facilitate the spread of Christianity among the Indigenous populations of the Empire by sending missionaries among them. The missionaries were there, above all, to preach the gospel; but they were also expected to educate the Indigenes; and to get them to adopt European forms of clothing, housing and a capitalist work ethic. In particular, the missionaries should encourage their converts to drop their 'uncivilised' ways of life - a nomadic huntergatherer economy or communal forms of property - and move to the 'higher' and more 'civilised' economic and social norms of individual 


\section{CLAIMING A SECOND EMPIRE}

property, English property laws and a settled form of agriculture within European-style villages.

The outstanding example of such a development, held up for admiration in the Report, was the Kat River Settlement of 'Hottentots', Khoisan people within the Cape Colony, to whom land on the colonial frontier was allotted that had been taken from the Indigenous Xhosa people. The 'Hottentots' are reported to have worked hard to cut canals and to have grown

an abundance of pumpkins, Indian corn, peas, beans, \&c.; they have enthusiastically taken to churches, schools and temperance societies; they now cost the government nothing and pay taxes like the settlers; and they even help to make the frontier of the colony safe, having repulsed the Caffres on every occasion on which they have been attacked. ${ }^{28}$

Lieutenant-Governor Stockenstrom emphasised the extent of their assimilation of European ideas of property and property law with a somewhat bizarre compliment: 'Instead of apathy or indifference about property, they become (now that they had property to contend for) as covetous and litigious about land and water as any other set of colonists. ${ }^{29}$ Similar examples are used to describe the success of missionaries among the people of the south Pacific ${ }^{30}$ and among the 'Indians' of Canada. ${ }^{31}$

The Reverend William Ellis, one of the LMS group stationed in the south Pacific, for example, stated approvingly:

Christianity condemned indolence, required industry, and supplied inducements to labour; and the natives, since they embraced Christianity, have acquired a knowledge of a number of useful manual arts ... they have been taught to build neat and comfortable houses, and to cultivate the soil . . But now they have new wants; a number of articles of clothing and commerce are necessary to their comfort, and they cultivate the soil to get them. ${ }^{32}$

A British missionary collaborating with Americans in the mission in the Sandwich Islands (Hawai'i) similarly testified that missionaries taught their converts 'useful trades', with the result that

instead of their little contemptible huts along the sea beach there will be a neat settlement, with a large chapel in the centre capable of containing 1,000 or 2,000 people, a school-house on the one side, and the chief's or the missionary's house on the other, and a range of white cottages a mile or two miles long ... so that their comfort as well as their happiness is increased, and altogether their character is elevated. ${ }^{33}$

An informant from the North American colonies described the effect of conversion to Christianity upon the 'Missisaguas' (Mississaugas) and 


\section{IMPERIAL EXPANSION AND ITS CRITICS}

'Chippeways' (Ojibwas) as being that 'they became industrious, sober and useful'. The Christian 'Chippeways' were said to have abandoned their 'wandering state, living in wigwams', and settled down in houses of wood and brick with domestic possessions, where they cultivated the soil for vegetables and fruits. Conversion to Christianity was said to have changed the Mohawks from the most 'drunken, ferocious and vicious' of the Six Nations to become 'changed in their dispositions, and reformed in their lives, teachable, sober, honest and industrious; and [they] are improving in the arts of civilization, and cultivating the virtues and charities of Christian life' ${ }^{34}$

The Committee was concerned also to protect Indigenous peoples against unrestrained slaughter and dispossession by colonists, and also against gross injustice or exploitation at White hands..$^{35}$ The Report recommended that Indigenous peoples should have their persons and property protected by the executive /colonial governors or the British government) rather than by local legislatures dominated by settlers. It recommended that the considerable revenues which the colonies received from the sale of Indigenous peoples' lands should be used to provide Indigenes with education, religious instruction and protection. In the case of Australia, specifically, it recommended the establishing of 'Protectors of Aborigines' ${ }^{\prime 36}$ - which would result in such protectors being appointed for the areas of South Australia and the Port Phillip district (in which British colonisation was beginning at the time the Select Committee was sitting) and in the colony of New Zealand.

The members of the Committee were critics of the impact on the lives of Indigenous peoples of unrestricted colonial expansion, and they wanted colonists to be prevented from acquiring any new territory without the sanction of an Act of the British Parliament. But their focus of concern was framed firmly within the context of the British Empire; they did not normally recommend contracting the boundaries of the Empire or returning land to its Indigenous owners. A rare exception was in relation to the eastern frontier of the Cape when they commended the Colonial Secretary Glenelg's order to Governor D'Urban to abandon Xhosa territory that the governor had annexed at the conclusion of hostilities in 1835, to which he had given the name 'Queen Adelaide Province'. Glenelg had insisted on the return of the land to the Xhosa, with withdrawal of settlement to the previous frontier of the Great Fish River. $^{37}$

Overall, the evangelicals saw the righteousness of the 'civilising mission' as justification enough for expansion of White settlement provided proper procedures were sustained. As Dr John Philip, a leading missionary in the Cape and major witness to the Select Committee, had put it a few years earlier: 


\section{CLAIMING A SECOND EMPIRE}

While our missionaries beyond the borders of the colony of the Cape of Good Hope are everywhere scattering the seeds of civilization, social order and happiness, they are by the most unexceptional means, extending British influence and the British empire. Wherever the missionary places his standard among a savage tribe, their prejudices against colonial government give way; their dependence upon the colony is increased by the creation of artificial wants; so confidence is restored, intercourse with the colony is established, industry, trade and agriculture spring up; and every genuine convert among them made to Christian religion becomes the ally and friend of the colonial Government. ${ }^{38}$

It is clear that the Select Committee was concerned that Indigenous peoples should be regarded and treated as human beings, with legal rights to be protected - not to be treated as animals to be shot, or as part of the natural landscape to be cleared away in the name of progress. But this does not mean that - though they later modified their views - they advocated full racial equality for Indigenous peoples in terms of acceptance of their existing cultures and societies. Nor did they advocate complete respect for, or protection of, the rights of all Indigenous peoples to their land. ${ }^{39}$ The general political orientation of the evangelicals of the Select Committee was one of paternalism. ${ }^{40}$ As clear as they were that Indigenous peoples were fully entitled to be protected from harm, the evangelicals were equally clear that they needed to be treated like children, to be guided, educated and told what to do by their 'natural superiors'. Once in the process of being transformed Indigenous people could acquire the rights of full citizenship.

The evangelicals saw the world in terms of the 'four-stage scheme of history' propounded by the Scottish Enlightenment. Stage one was the world of nomadic hunter-gatherers; second came the stage of nomadic pastoralism; third, subsistence agriculture; and the final stage was their own world of mercantile capitalism. Each successive stage required a greater division of labour and a more complex social organisation, and hence represented an advance in civilisation. ${ }^{41}$ The scheme involved the belief that European history had actually passed through these four stages over the course of centuries; in addition, as Europeans 'discovered' new areas of the world to be colonised, those who developed the scheme tended to identify the Indigenous peoples whom they encountered in terms of one of these stages, according to their economic practices and social structures. Since none of the Indigenous peoples of the British colonies of settlement had yet developed mercantile capitalism, the evangelicals of the Select Committee tended to rank them in a hierarchy of stages one to three, regarding as the 'most civilised' those who practised the subsistence agriculture of stage three, and the 'least civilised' the nomadic hunter-gatherers. 


\section{IMPERIAL EXPANSION AND ITS CRITICS}

This is best illustrated by the Report's remarks about the Australian Aborigines. Early on, the Report stated, in a context which clearly included Australia:

It might be presumed that the native inhabitants of any land have an incontrovertible right to their own soil: a plain and sacred right, however, which seems not to have been understood. Europeans have entered their borders uninvited, and, when there, have not only acted as if they were undoubted lords of the soil, but have punished the natives as aggressors if they have evinced a disposition to live in their own country. ${ }^{42}$

This would appear to be an unambiguous statement that the Aborigines had a clear right to their land, which had been unjustly taken from them. But the Report subsequently stated, about all the Indigenous peoples in the British Empire: 'To this variety in their circumstances must be added a variety as great in their moral and physical condition. They are found in all the grades of advancement, from utter barbarism to semi-civilization.' In its specific 'Suggestions' for Australia, it described the Australian Aborigines as 'forming probably the least-instructed portion of the human race in all the arts of social life'. It went on to say:

Such, indeed, is the barbarous state of these people, and so entirely destitute are they even of the rudest forms of civil polity, that their claims, whether as sovereigns or proprietors of the soil, have been utterly disregarded. The land has been taken from them without the assertion of any other title than that of superior force and by the commissions under which the Australian Colonies are governed Her Majesty's sovereignty over the whole of New Holland is asserted without reserve.

This statement - that the land was simply taken from the Aborigines without any legal title and in disregard of their ownership of it - would seem to imply that it should now be restored to them; but the Report in fact continued:

It follows, therefore, that the Aborigines of the whole territory must be considered as within the allegiance of the Queen, and as entitled to her protection. Whatever may have been the injustice of this encroachment, there is no reason to suppose that either justice or humanity would now be consulted by receding from it. ${ }^{43}$

Unlike the recommendation about withdrawal from occupied Xhosa territory on the Cape frontier, ${ }^{44}$ the Report did not recommend any withdrawal from the British claim to own the whole of Australia - even though none of it had been formally acquired, by conquest, treaty or sale, from its Aboriginal owners. The Select Committee was certainly concerned to protect the Indigenous peoples of the Empire against gross 
exploitation or violence; but their protection was essentially one of paternalism, which did not at this stage concede full equality.

The Select Committee's recommendations were made for all the colonies that it considered; and its members had some concrete influence on British colonial policy in London, and on some colonial officials, in relation to policies towards Indigenous peoples in Australia, Canada, South Africa and New Zealand. However, the extent and importance of that personal influence at this time should not be overstated. They were most pronounced when the evangelical influence over British colonial policy was at its height, in the late 1830s and the 1840s; but that influence would wane thereafter. On the other hand, the notion that, once 'civilised', an Indigene deserved full citizenship was an ideal that persisted beyond the evangelicals' temporary hold on the Colonial Office, and the evangelicals acted as a goad to British governments to uphold this principle. In 1847 the APS founded its journal Colonial Intelligencer; or Aborigines' Friend to convey to church people 'interesting intelligence concerning the Aborigines of various climes; and articles upon colonial affairs; with comments upon the proceedings of government and of colonists towards native tribes' ${ }^{45}$ This journal would go out monthly to the faithful in Protestant churches across the country and to humanitarians in the colonies, and would sustain a critique of the Colonial Office and its administration that would not be without effect.

An important factor in the sharp boundaries placed on the implementation of even humanitarians' limited ideals in settler colonies was the impact of the second report that affected ideas about colonists' political rights: the Durham Report, of 1839.

\section{The Durham Report}

The Durham Report arose out of the so-called 'rebellions' of 1837 in Upper and Lower Canada in which first certain French settlers and then a group of British settlers sought to wrest control of their affairs away from the British administration. Once the unsettling movement had been crushed, the British Parliament suspended the Legislative Assembly of the French-inhabited Lower Canada (Quebec) for two years, and sent out a governor-general and high commissioner with the brief of solving the problem of the future form of government in Upper and Lower Canada. The man chosen for the role was Lord Durham, a minister in the Government of his father-in-law Lord Grey that had passed the First Reform Act, and popularly known as 'Radical Jack' for his support of parliamentary reform. ${ }^{46}$ Durham lasted only five months in the post before resigning in a huff and returning to England. But he 


\section{IMPERIAL EXPANSION AND ITS CRITICS}

took with him to Canada two British radicals concerned with the reform of colonial government, Charles Buller and Edward Gibbon Wakefield. Once back in England, Durham or, more accurately, Buller - with some help from Wakefield - wrote the famous Report, which Durham presented to Parliament in January $1839 .{ }^{47}$

Unlike the Select Committee's Report of only a couple of years before, Durham's showed no concern at all for the rights or conditions of the Indigenous peoples. When, in the opening passages, he wrote about Canada, 'I expected to find a contest between a government and a people; I found two nations warring in the bosom of a single state; I found a struggle not of principles but of races', Durham was referring, not to a struggle between European and Indigenous Canadians, but to the conflict between French and British settlers. ${ }^{48}$ Durham's preoccupation was with the White settlers of Canada, and how they might be prevented from following the American example and demanding independence from Britain.

His solution - initially for Canada, and subsequently extended to all the other British colonies of settlement - was to grant political rights of self-government to the settlers. This was to be done constitutionally in two stages. First should come 'representative government', under which the White settlers were able to elect a legislature, but the executive continued to be a governor appointed by the British Crown. At the second stage would follow 'responsible government', under which principal authority and power would lie (as in the British Parliament) with an executive of prime minister and cabinet chosen by, and responsible to, the elected legislature.

Even under 'responsible government', although the colonists would be given almost full control of their own internal affairs, the British government would retain control of: the colony's political constitution; the colony's foreign relations and trade with Britain, other British colonies and foreign nations; and the disposal of public lands (which in Canada involved 'Indian' policy) in the colony. But, with those exceptions, the colonists would govern themselves. The essential argument was that giving the White settlers powers of self-government, but still under the British Crown, would keep them loyal to the Empire and prevent another American-style revolution against British rule. To solve the French-British 'race' problem, the Report recommended that Upper and Lower Canada should be united into a single colony, to ensure a British settler majority. This would be done almost immediately, by an Act of 1840 .

The Report's recommendation that the British Government should extend responsible government to the existing colonies - Upper Canada (Ontario), Lower Canada (Quebec), and the maritime colonies of Nova 
Scotia, New Brunswick, Prince Edward Island and Newfoundland - was not immediately acted upon. But in 1847, the Whig Government, with the third Earl Grey (son of the former prime minister and brother-inlaw of Lord Durham) as secretary of state for the colonies, granted Nova Scotia responsible government. This became the model for subsequent colonial development: during the second half of the nineteenth century, all the British colonies of settlement followed this pattern of development, at different periods, depending on their date of foundation as colonies, and the nature of their social, economic and political structure and problems.

A crude model of what happened to Indigenous political rights in British colonies of settlement in the second half of the nineteenth century might go something on these lines: as political power was devolved from London to the separate self-governing colonies, the political rights of the Indigenous peoples were accordingly diminished. We move from the Select Committee's 1830s' concern, to apply a single moral standard for the treatment of Indigenous peoples throughout the Empire, to the early twentieth-century White politicians, in the different colonies of that Empire, passing laws for their own local criteria to be applied in deciding whether or not to admit Indigenous peoples to full political rights. The basic explanation of how this happened lies in the grant of responsible government to these colonies, which removed the Indigenous peoples of those countries from the salutary protection of the single policy emanating from the Colonial Office in London.

That schematic model, however, would over-simplify a more complex set of developments. First, as we have shown, even when the evangelicals of the Select Committee exercised substantial influence over policy throughout the Empire, they did not advocate complete equality or full political rights for Indigenous peoples unless and until they resembled culturally the colonists, who remained the standard of human development. Second, as we show in the chapters that follow, developments across the colonies of settlement were uneven, in both timing and outcome. The Colonial Office continued to maintain a general principle against placing explicit colour bars in the colonial legislation governing political rights; but the settler colonies differed markedly in their willingness to observe that principle, and in the sincerity with which they tried to carry it out or evade its effects. A few colonial governments were prepared to depart from this principle even in theory, and most of them departed from it in practice, in their handling of the issue of political rights for the Indigenes of their colonies.

The Durham Report was silent on the issue of the effect on Indigenous political rights of the extension of powers of self-government to settlers of European origin. As things worked out between the 1830s and 1910, 


\section{IMPERIAL EXPANSION AND ITS CRITICS}

the admission of Indigenous peoples to formal political rights was related to the extension of representative and responsible government in the colonies - but unevenly and irregularly so: there was no uniformity of development. By 1910, the extent of the political rights secured by Indigenous peoples varied considerably according to the country or colony in which they lived. One of the purposes to which settlers could put their powers of self-government was the control of political rights for their local Indigenes. Events and issues particular to each colony could influence the local outcome; where significant, these are discussed in the specific chapters on each country.

We commence with a review of the introduction of self-governing institutions in the settler colonies, from the late 1830s' debates of the evangelicals and the Durham Report through to 1870.

\section{Notes}

1 See Andrew Porter, 'Introduction: Britain and the Empire in the Nineteenth Century', in Andrew Porter (ed.), The Oxford History of the British Empire, vol. 3: The Nineteenth Century (Oxford: Oxford University Press, 1999).

2 Ibid., p. 5. See also: R. Hyam, 'The British Empire in the Edwardian Era', in Judith M. Brown (ed.), The Oxford History of the British Empire, vol. 4: The Twentieth Century (Oxford: Oxford University Press, 1999).

3 See G. Martin, 'The Idea of "Imperial Federation"', in Ronald Hyam and Ged Martin, Reappraisals in British Imperial History (London: Macmillan, 1975).

4 The Times, 25 April 1911.

5 The Times, 24 May 1911.

6 The Times, 18 May 1911.

7 The Times, 22 April 1911.

8 The Times, 22 June 1911.

9 Anti-Slavery Reporter and Aborigines' Friend, October (1911), pp. 106-7.

10 Ibid.

11 For summaries of early settlement in Canada, Australia and New Zealand, see the chapters by Ken Coates, Henry Reynolds and M. P. K. Sorrenson in Paul Havemann (ed.), Indigenous Peoples' Rights in Australia, Canada, and New Zealand (Wellington: Oxford University Press, 1999), pp. 123-80.

12 For a general history see J. R. Miller, Skyscrapers Hide the Heavens: A History of Indian-White Relations in Canada (Toronto: University of Toronto Press, 2000 [1989]).

13 Ibid.

14 The Bantu-speakers of Southern Africa are divided into two broad linguistic groups - the Nguni-speakers (Xhosa, Zulu, Swazi, Ndebele) and the Sotho-Tswana group (North and South Sotho, Tswana). The Dutch, and then the British, tended to refer to the Xhosa (and, subsequently, to all Black Africans) as Kaffirs - derived from the Arabic kafir (unbeliever); sometimes spelt 'Kafir' or 'Caffre'. It is not an African word, and generally carried (and still carries) a derogatory connotation.

15 M. Wilson, 'Co-operation and Conflict: The Eastern Cape Frontier', in M. Wilson and L. Thompson (eds), The Oxford History of South Africa, 2 vols (New York: Oxford University Press, 1969), vol. 1, pp. 233-71. For frontier wars, see Noel Mostert, Frontiers: The Epic of South Africa's Creation and the Tragedy of the Xhosa People (London: Jonathan Cape, 1992).

16 See A. Frost, 'New South Wales as Terra Nullius: The British Denial of Aboriginal Land Rights', in S. Janson and S. Macintyre (eds), Through White Eyes (Sydney: Allen 


\section{CLAIMING A SECOND EMPIRE}

\& Unwin, 1990); R. Hunter, R. Ingleby and R. Johnstone (eds), Thinking About Law: Perspectives on the History, Philosophy and Sociology of Law (Sydney: Allen \& Unwin, 1994); K. Neumann, N. Thomas and H. Ericksen (eds), Quicksands: Foundational Histories in Australia and Aotearoa New Zealand (Sydney: University of NSW Press, 1999).

17 See for example Niel Gunson (ed.), Australian Reminiscences of L. E. Threlkeld, Missionary to the Aborigines, 1824-1859, 2 vols (Canberra: Australian Institute of Aboriginal Studies, 1974).

18 For the early history of the Australian colonies see: Donald Denoon and Philippa Mein-Smith, The History of Australia, New Zealand and the Pacific (London: Blackwell, 2001); Ann McGrath (ed.), Contested Ground: Australian Aborigines Under the British Crown (Sydney: Allen \& Unwin, 1995); Henry Reynolds, The Other Side of the Frontier: Aboriginal Resistance to the European Invasion of Australia (Townsville: James Cook University Press, 1981).

19 For the early history of New Zealand see: Peter Adams, Fatal Necessity: British Intervention in New Zealand, 1830-1847 (Auckland: Auckland University Press, 1977); James Belich, Making Peoples: A History of the New Zealanders (Auckland: Allen Lane, 2001); Claudia Orange, The Treaty of Waitangi (Wellington: Allen \& Unwin, 1987).

20 See D. M. Young, The Colonial Office in the Early Nineteenth Century (London: Longmans, 1961); Peter Burroughs, 'Imperial Institutions and the Government of Empire', in Porter (ed.), The Oxford History of the British Empire, vol. 3; J. H. Rose, A. P. Newton and E. A. Benians (eds), The Cambridge History of the British Empire (Cambridge: Cambridge University Press, 1929-36), vol. 3 (1933): EmpireCommonwealth 1870-1919.

21 Report of the Select Committee on Aborigines (British Settlements) with Minutes of Evidence, British Parliamentary Papers (1836, vol. 7, Evidence; 1837, vol. 7, Report) (hereafter: Report).

22 Report on the Affairs of British North America, British Parliamentary Papers (1839), vol. 32, pp. 1-690 (hereafter: Report). The Report has also been published in a number of editions, such as Lord Durham's Report: An Abridgement of the Report on the Affairs of British North America, ed. G. M. Craig (Toronto: McClelland \& Stewart, 1963).

23 See: I. Bradley, The Call To Seriousness. The Evangelical Impact on the Victorians (London : Jonathan Cape, 1976); F. K. Brown, Fathers of the Victorians (Cambridge: Cambridge University Press, 1961); E. M. Howse, Saints in Politics. The 'Clapham Sect' and the Growth of Freedom (London: Allen \& Unwin, 1953); B. Hilton, The Age of Atonement: The Influence of Evangelicalism on Social and Economic Thought, 1795-1865 (Oxford: Clarendon Press, 1988).

24 See Thomas Fowell Buxton, in C. Buxton (ed.), Memoirs of Sir Thomas Fowell Buxton (London: John Murray, 1855).

25 See Z. Laidlaw, 'Integrating Metropolitan, Colonial and Imperial Histories: The Aborigines Select Committee of 1835-37', in Tracey Banivanua-Mar and Julie Evans (eds), Writing Colonial History (Melbourne: RMIT Publishers, 2002); Alan Lester, Imperial Networks: Creating Identities in Nineteenth-Century South Africa and Britain (London: Routledge 2001), pp. 106-23; R. Milliss, Waterloo Creek. The Australia Day Massacre of 1838, George Gipps and the British Conquest of New South Wales (Ringwood, Victoria: Penguin, 1992), pp. 123-7, 226-33.

26 Report, British Parliamentary Papers (1837), vol. 7, p. 5.

27 Ibid., p. 76.

28 Ibid., pp. 61-4.

29 Ibid., p. 62.

$30 \quad$ Ibid., pp. 51-8.

31 Ibid., pp. 47-50.

32 Ibid., p. 50 (emphasis in original)

33 Ibid., p. 56.

34 Ibid., p. 49. 


\section{IMPERIAL EXPANSION AND ITS CRITICS}

35 This point was made powerfully, again by Lieutenant-Governor Stockenstrom, in relation to his recommended ways of dealing with the Xhosa on the eastern frontier of the Cape: 'the main point I would have in view would be trade, commerce, peace and civilization. The other alternative is extermination; for you can stop nowhere; you must go on; you may have a short respite when you have driven panic into the people, but you must come back to the same thing until you have shot the last man': Report, British Parliamentary Papers (1836), vol. 7, p. 244: Evidence of Stockenstrom, 1 March 1836.

36 Report, British Parliamentary Papers (1837), vol. 7, pp. 83-4.

37 Ibid., p. 18.

38 John Philip, Researches in South Africa (1828), pp. ix-x, quoted in Stanley Trapido, "The Friends of the Natives": Merchants, Peasants and the Political and Ideological Structure of Liberalism in the Cape, 1854-1910', in S. Marks and A. Atmore (eds), Economy and Society in Pre-Industrial South Africa (London: Longman, 1980), pp. $247-74$, at 249.

39 The Australian historian Henry Reynolds calls the Select Committee and its recommendations 'the First Land Rights Movement' in relation to Australia in his The Law of the Land (Ringwood, Victoria: Penguin, 1992 [1987]), chapter 4. A serious examination of the Select Committee and its recommendations simply cannot sustain this view - see below.

40 Bradley, Call to Seriousness; D. Roberts, Paternalism in Early Victorian England (London: Croom Helm, 1979).

41 See Adam Smith, Lectures on Jurisprudence, ed. R. L. Meek, D. D. Raphael and P. G. Stein (Oxford: Clarendon Press 1978); P. G. Stein, Legal Evolution: The Story of an Idea (New York: Cambridge University Press, 1980).

42 Report, British Parliamentary Papers (1837), vol. 7, p. 5.

43 Ibid., pp. 76, 82-3.

44 Ibid., p. 18.

45 Colonial Intelligencer; or Aborigines' Friend (hereafter: Colonial Intelligencer), April (1847), p. 1.

46 See M. Brock, The Great Reform Act (London: Hutchinson, 1973).

47 On the historical context of the Durham Report, and its subsequent reception and influence, see: J. R. M. Butler, 'Colonial Self-Government 1838-1852', in J. H. Rose, A. Newton and E. A. Benians (eds), The Cambridge History of the British Empire, 2 vols (Cambridge \& New York: Cambridge University Press, 1938-40), vol. 2, pp. 335-87; G. Martin, The Durham Report and British Policy. A Critical Essay (Cambridge: Cambridge University Press, 1972).

48 See Craig's Introduction (p. iv) to Lord Durham's Report: An Abridgement; and K. McNaught, The Penguin History of Canada (New York: Viking Penguin, 1988), p. 94. That particular usage, by imperial observers, of 'races' to describe the conflicts between two White colonial nationalities applied not only to French-English hostilities in Canada, but subsequently to English-Afrikaans conflicts in South Africa. 
Julie Evans, Patricia Grimshaw, David Philips, and Shurlee Swain - 9781526137333 Downloaded from manchesterhive.com at 04/26/2023 03:22:25AM 